\title{
Peertechz
}

\section{Stormwater management a case study of Nashik city}

\section{Sakshi R Chandwadkar, Mayuri N Gangode*, Harshada S Bhamare and Mrunal S Pawar}

Department of Civil Engineering, Maratha Vidya Prasarak Samaj's Karmaveer Baburao Ganpatrao Thakare College Of Engineering, Udoji Maratha Boarding Campus, Gangapur Road, Nashik, Maharashtra 422013, India
Received: 24 November, 2021

Accepted: 03 January, 2022

Published: 04 January, 2022

*Corresponding author: Mayuri N Gangode, Student Department of Civil Engineering, Maratha Vidya Prasarak Samaj's Karmaveer Baburao Ganpatrao Thakare College Of Engineering, Udoji Maratha Boarding Campus, Gangapur Road, Nashik, Maharashtra 422013 , India, Tel: 9881910329;

E-mail:mayurigangode2000@gmail.com

Keywords: Rainfall; Runoff; Stormwater drains; Flooding

Copyright License: (c) 2022 Chandwadkar SR, et al. This is an open-access article distributed under the terms of the Creative Commons Attribution License which permits unrestricted use, distribution, and reproduction in any medium, provided the original author and source are credited.

https://www.peertechzpublications.com

Check for updates

\begin{abstract}
Stormwater management means to manage surface runoff. Stormwater management can reduce the runoff of rainwater. It includes controlling flooding and reducing erosion to improve water quality. This Strategy used in our Nasik city (Untwadi Road Signal) to prevent the impacts of Stormwater. We know that, in rainy season the water is flow over the ground surface. This rainwater does not have any suspended solid, it collects in drainage which flow by the force of gravity and then it discharges near lake or river. Urbanization reduces the infiltration rate of lands it causes of the flooding it occurs scouring and waterlogging problem. So, it is necessary to identify area of problem and suggest BMPs (Best Management Practices) techniques.
\end{abstract}

\section{Introduction}

Due to urbanization of city the infiltration of land is reduce; it results in the low infiltration of rain water in the ground. The stormwater runoff occurs when the rain falls over the infiltration land such as roadway, walk way, parking lots, rooftop and other surface that prevent the infiltration of stormwater. This runoff volume increase and flooding problems are generated in city $[1,2]$. The runoff is exited in the drain in near lake and river. The sedimentation, nitrogen, bacteria, phosphorus, oil, grease, trash, pesticides, metal and other matter present in the environment also pollute the stormwater in urban areas is more in sewer line to meet the sewage water its more pollute, after drains in lake or river the other industrial wastewater pollutes the stormwater. The Stormwater management practice is used to prevent the pollution and to store in tanks is the science of stormwater runoff management. To avoid adverse impacts on the environment $[3,4]$. The main goal is to manage water quantity and analysis of problems associated with of stormwater impact, and give analytical solution to it.

\section{Objective: Level 1}

1) Identify problems associated with the study area "Untwadi road Nashik"

2) To study the drainage system of study area and give good solution to the problems.

3) To solve the problem of traffic congestion during rainy season.

4) To discontinue the sewage which is generated from the source.

\section{Problem statement: Level 1}

1) After survey of study to area, identify problem of the Stormwater in the city both side of road provided the Stormwater drain line network to discharge of Stormwater in Nasadi river [5,6].

2) The inadequate storm drainage network does not remove 
stormwater, due to the low belt in the topography near the signal the runoff of water from multiple directions is diverted towards the low belt Figure 1.

3) This Nasardi flows discharges by Industrial and Residual sewer system. Stormwater runoff polluted on Ground surface such contain as vehicle dropping oil and grease, metal, sediments, nitrogen, trash, phosphorus, pesticides, bacteria and other. The impervious area reduces the infiltration. In rainy season the water is flow over the ground surface. This rainwater does not have any impurity, it collects in drainage flow by a force of gravity and then it discharge near lake or river. Stormwater runoff polluted by oil and grease which is dropped by vehicles, metal, sediments, nitrogen, trash, phosphorus, pesticides, bacteria and other Figure 2.

4) Due to flooding erosion of the pavements due to flooding. Stormwater is the main source of freshwater its drain through discharge into river and we have to store this water for domestic purpose Figure 3.

5) The storm drainage line due sedimentation not properly work the debris close the storm drain [7-11].

\section{Study area: Level 1}

The study has been focused on the small area in Nashik: untwadi road. It is located near the bank of Nasardi River having latitude $19.9906^{\circ} \mathrm{N}$ and longitude $73.7621^{\circ} \mathrm{E}$. It is one of the congested areas in Nashik where problem of water logging occurs frequently. Due to this there is major loss of property and deterioration of road, which affect the economy of the city. The existing stormwater drains in this area are constructed many years ago and the size of drains is small this cause increase in the volume of runoff water Figures 4,5 .

\section{Sources: Level 2}

This is the list of industries near Nasardi river: -

- R.K. Industries

- H.K. Industries

- District Industries Centre

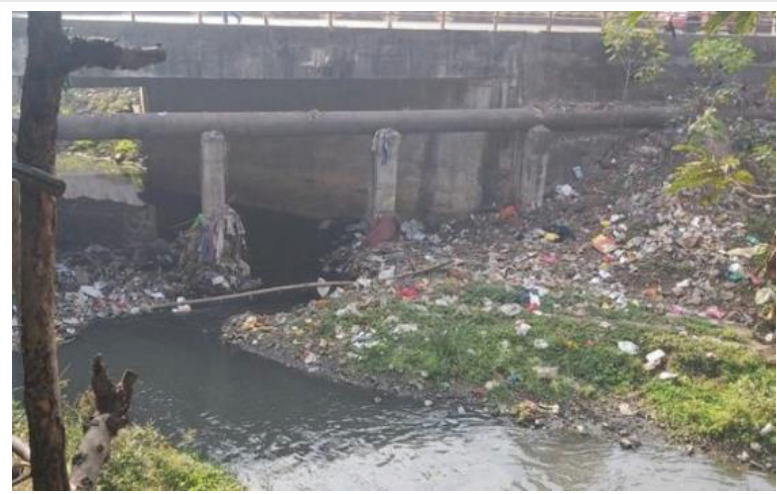

Figure 1: Drainage system near untwadi road.

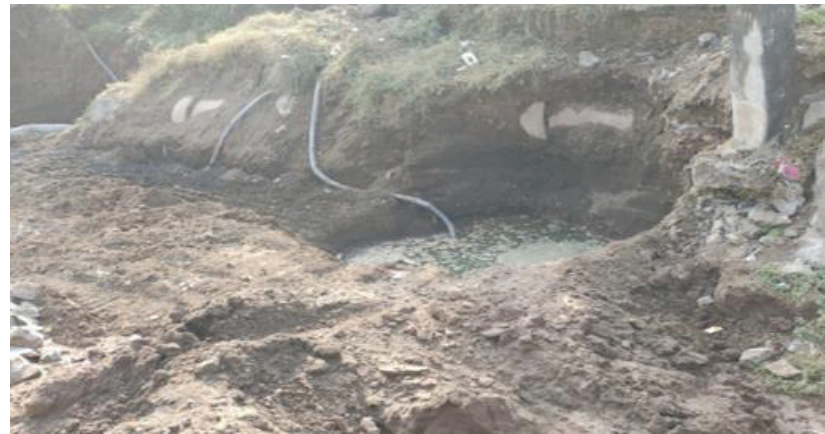

Figure 2: Impervious area.

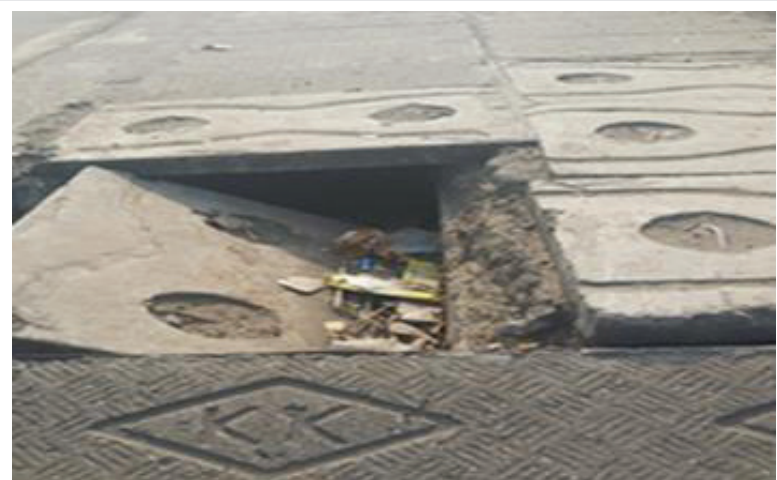

Figure 3: Condition of manhole.
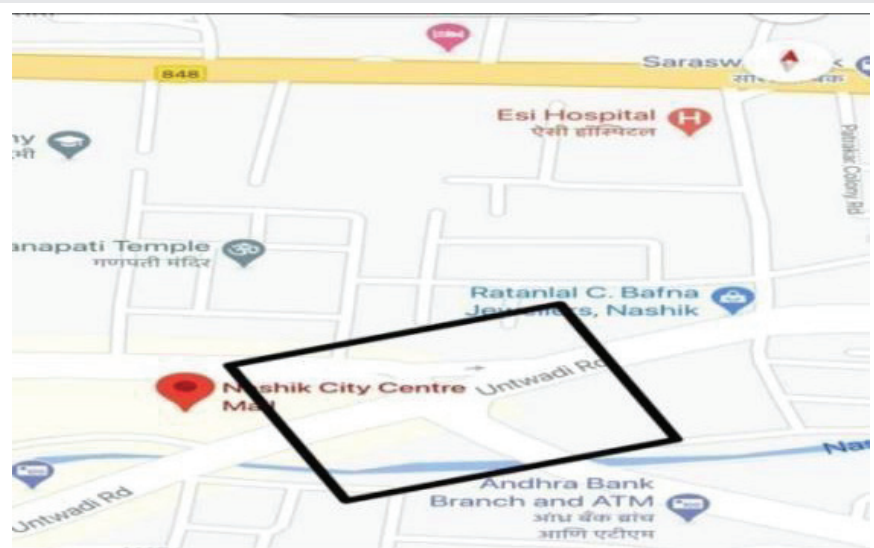

Figure 4: Study area.

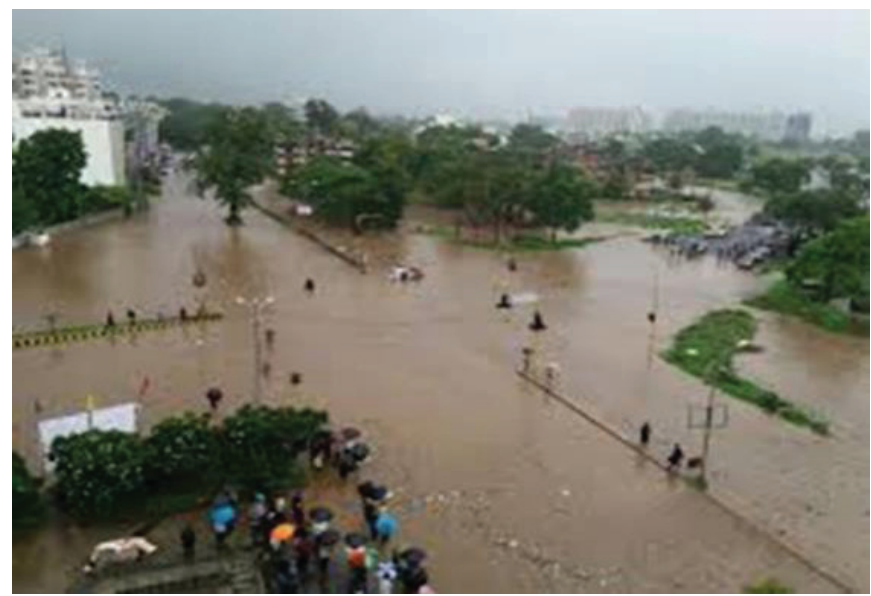

Figure 5: Nashik on high alert on heavy rainfall.

Citation: Chandwadkar SR, Gangode MN, Bhamare HS, Pawar MS (2022) Stormwater management a case study of Nashik city. J Civil Eng Environ Sci 8(1): 001-003. DOI: https://dx.doi.org/10.17352/2455-488X.000044 


\section{- S.N. Industries}

- Rudra Industries

\section{- Automation Industries}

\section{Proposed solution: Level 3}

After the existing survey of study area, we identify the problem of stormwater. We identified that the Nasadi river is polluted a lot because of sewage coming from the sources due to which it reduces the capacity of river. Therefore, we came to a solution that it is mandatory to provide Effluent Treatment Plant at each at every industry through which the sewage is being discharged When we observe the area we saw that there the stormwater line is not installed so the second solution we can give is to install a stormwater drainage line which starts from Sambhaji Chowk as it have low topography and then it discharge it into the Nasadi River Figures 6,7.

\section{Conclusions}

1) The literature review study shows that there is a scope for studying and analyzing to identify the problem in given study area and provide best management practices to prevent the impact of stormwater.

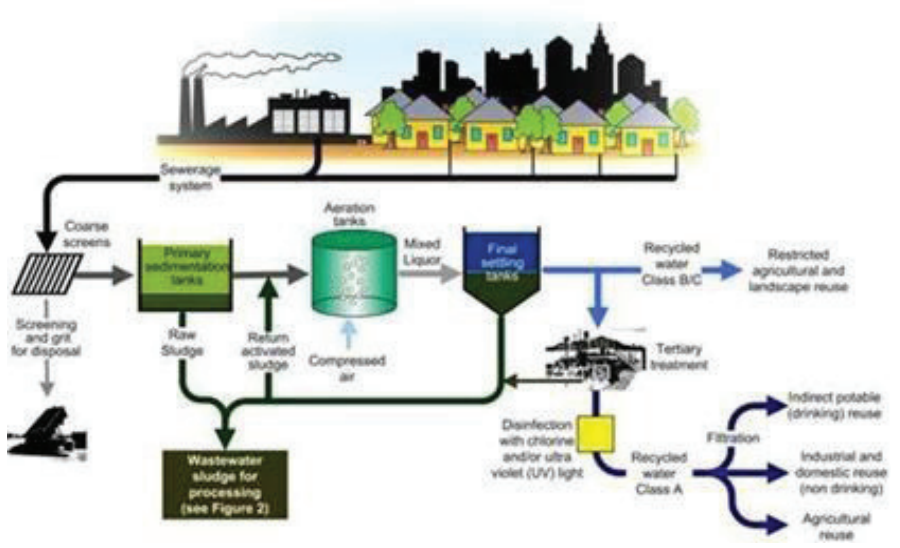

Figure 6: Influent treatment plant for industrial wastewater.

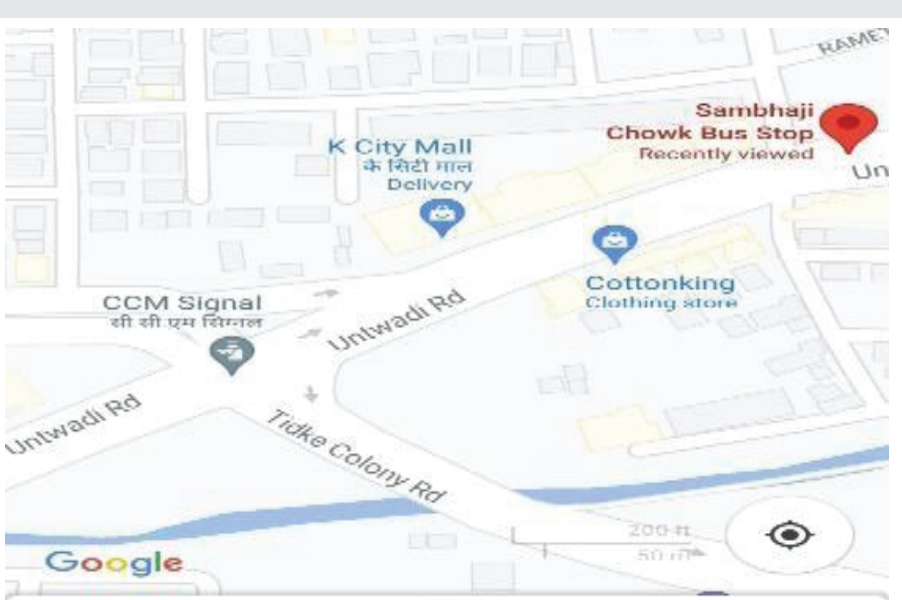

$\&$ Sambhaji Chowk Bus Stop
2) After studying we came across different problems such as the stormwater line is not provided in our study area so providing stormwater line at low belt.

3) Discontinue the sewage coming from different sources.

\section{Acknowledgments}

We have great pleasure in presenting project report on "Stormwater Management: A Case Study of Nasik City (Untwadi Road Signal) "It gives us immense pleasure to express a deep sense of gratitude to guide Prof. M. B. Patil for his valuable suggestions, guidance and motivation during entire Project work. With deep sense of gratitude, we thank to our principal Dr. S. R. Devane and management of the MVPS's KBTCOE, NASHIK for providing all necessary facilities and their constant encouragement. We thankful to all faculty members of the civil department for their support, help and guidance and also for their esteemed suggestion. We also like to thank my colleagues for their contribution in making a successful completion of project work.

\section{References}

1. Rashmi D, Mayuri C, Bhavar (2018) Street Stormwater, harvesting for Nashik city. Int $\mathrm{J}$ Res Engineering Applica Manage (IJREAM) Link: https://bit.ly/3mRLVpl

2. Parmar SB, Bhavsar VD (2017) Storm water management a case study of Gandhinagar city (Gujrat) Int Res J Eng Technol (IRJET) 4: 1440-1442. Link: https://bit.ly/3pLy2v6

3. Migosi P (2014) Effects of urban storm water management strategy in reducing flooding, a case of Mombasa. IJREAM 2: 82-90. Link: https://bit.ly/3FTgp2a

4. Akram F, Rasul MG, Khan MMK, Amir MS (2014) A review on stormwater harvesting and reuse. Int J Environ Ecolog, Geolog Mining Eng 8: 188-197. Link: https://bit.ly/3qKyMQd

5. Gautam MR, Acharay K, Stone M (2010) Best management practices for stormwater Management in Desert Southwest. J Cntempor Water Res Educat 146: 39-49. Link: https://bit.ly/3qGThNJ

6. Morgan S, Celik S, Retzlaff W, Road G (2014) Strom Water Runoff Quantity and Quality. J Environ Eng Am Soc Civil Eng (ASCE).

7. Chahar BR, Graillot D, Gaur S (2012) Stormwater Management through Infiltration Trenches. Journal of Irrigation and Drainage Engineering 138: 274281. Link: https://bit.ly/3sRMjYV

8. Machusick M, Welker A (2011) Groundwater Mounding at a Stormwater Infiltration BMP. J Irrigation Drainage Engineering. Link: https://bit.ly/3zy3dol

9. Pita SK, Santhi T, Manoj Shrivastava P, Shreekanth Reddy SV, Anjaneya Prasad M, et al. (2015) Stormwater Drainage Design (case study Vijayawada). J Earth Sci Eng 8: 507511. Link: https://bit.ly/3FR3sWy

10. Villarreal EL (2019) Water saving and runoff retention potentials of a rainwater collection system in a University building in Colombia NOVA TECH.

11. Gogate NG, Raval PM (2015) Identifying objectives for sustainable stormwater Management in urban Indian perspective: a case study. Int J Environ Eng 7: 143-162. Link: https://bit.ly/3pNyVTN

Citation: Chandwadkar SR, Gangode MN, Bhamare HS, Pawar MS (2022) Stormwater management a case study of Nashik city. J Civil Eng Environ Sci 8(1): 001-003. DOI: https://dx.doi.org/10.17352/2455-488X.000044 